\title{
African American Enslavement, Speech Act Theory, and the Law
}

\author{
Alexander Brown ${ }^{1}$ \\ Published online: 8 June 2019 \\ (C) The Author(s) 2019
}

\begin{abstract}
In the context of African American enslavement and the legacy of that enslavement, do some uses of the word "nigger" possess the power to enslave? It goes without saying that the words "negro," "nigger," "colored," and "black" are an important part of the language and discourse of African American enslavement - as terms used by slave owners, slave traders, slave catchers, and slaves themselves; as terms still used today by people living with the legacy of slavery; and as terms highlighted by academics in explaining these events and various other aspects of the African American experience. However, the aim of this article is to explore the role of these words as instruments of racial enslavement within the USA - past and present. To be more precise, the article argues that in several different ways relating to bodies of law, enforcement of law (or lack thereof), and the scope of law, the words "negro," "nigger," "colored," and "black" come to not simply mean "a slave" but actually to make African Americans slaves.
\end{abstract}

Keywords African American slavery · Speech act theory · The law · "Nigger"

\section{Introduction}

In the context of African American enslavement and the legacy of that enslavement, do some uses of the word "nigger" possess the power to enslave? It goes without saying that the words "negro," "nigger," "colored," and "black" are an important part of the language and discourse of African American enslavement - as terms used by slave owners, slave traders, slave catchers, and slaves themselves; as terms still used today against (and sometimes by) people living with the legacy of slavery; and as terms highlighted by academics in explaining these events and various other aspects of the African American experience (Kennedy 2003; Roberts 2010). However, the aim of this

Alexander Brown

alexander.c.brown@uea.ac.uk

1 School of Politics, Philosophy, Language and Communication Studies, University of East Anglia (UEA), Norwich Research Park, Norwich, Norfolk NR4 7JU, UK 
article is to explore the role of these words as instruments of racial enslavement within the USA - past and present. To be more precise, the article argues that in several different ways relating to bodies of law, enforcement of law (or lack thereof), and the scope of law, the words "negro," "nigger," "colored," and "black" come to not simply mean "a slave" but actually to make African Americans slaves.

Academic discussion of the word "nigger," along with other slurs and epithets, itself figures in much wider debates and controversies. These include whether the word "nigga" carries any lesser "slavery laden meaning" than the word "nigger" (Nelson 1998); whether certain groups have greater or lesser moral standing to use the words "nigger" or "nigga" (Kennedy 1999; Roberts 2010); whether the word "nigger" is an exemplar case of "hate speech" (Brown 2017a; Brown 2017b); whether the right response to the problem of such language is to ban it (Brown 2015), provide remedies in civil law (Delgado 1982; Brown 2018), or else, simply give groups the freedom they need to reclaim and resignify such terms (Butler 1997); and whether hate speech laws have become so politicized that banning the word "nigger" could exacerbate racial tensions (Brown and Sinclair 2019). However, I shall not seek to address these wider issues here.

The article is structured as follows. In the next section, I introduce speech act theory as a tool for thinking about what racists do with the word "nigger," including potentially enslaving people. I also explain how I will use a fictional (but at the same time quite familiar) political community called Usonia, as a device for getting to the heart of the question of whether the word "nigger" can enslave, and, if so, howespecially in the context of bodies of law. Following on from that, I argue that the use of the word "nigger" within bodies of law can enshrine, formalize, and enact slavery. I then explore how, even after the abolition of slavery, racist laws still give the word "nigger" the power to enslave. After that, I examine the effect of non-enforcement of discriminatory harassment laws: I argue that even with discriminatory harassment laws in place, practically the word "nigger" can still be used to enslave people largely due to said non-enforcement. I then look at the issue of the narrow scope of discriminatory harassment laws, namely, the fact that such laws are applied to certain protected zones like the workplace or college campuses, but not to other sorts of public places. Here, once again, I argue that the word "nigger" can still be used to enslave outside of these protected zones. Finally, I examine the role of civil courts, and the language sometimes used in courts, as another potential source of enslavement. However, in this case, I argue that certain linguistic missteps by courts do not enslave per se.

\section{Speech Act Theory: What Do Racists Do with the Word "Nigger"?}

The main theoretical architecture of my project will be speech act theory, the foundation stone of which is J. L. Austin's distinction between the act of saying something, that is, a locutionary act (I said to him, "You can't do that!"), what one is doing when one says something, an illocutionary act (I commanded that he must not do that), and the effect on the listener of what one is doing when one says something, a perlocutionary act (My words stopped him from doing that) (Austin 1962, p. 102). Other scholars have used speech act theory to interrogate the processes or mechanics by which persons and entire language communities perform illocutionary acts of race-ing 
other people by referring to them in racial terms (Morrison 1992). My contribution explores uses of the word "nigger" (and synonyms or related words) which amount to the performance of an illocutionary act of enslavement.

Of course, it would be quite absurd to think that the word "nigger" could perform such an act all by itself, or even that an ordinary user of the word "nigger" could do so all by him or herself. Other background or contextual elements are required in order to grant the word "nigger" such illocutionary force. In this article, I am particularly concerned with the role the law has played, and continues to play, in validating, facilitating, and even constituting illocutionary acts of enslavement involving the word "nigger." In saying that, I intend to focus on the law (by which I mean everything from laws themselves to the practices of justice system professionals and institutions of the law). However, I do not seek to deny the fact that social practices and institutions from across the spheres of politics, commerce, culture, media, sport, science, and medicine can enable enslaving uses of the word "nigger." I choose to concentrate on the law because it is one of the most crystallized and prominent elements and because it provides a coercive backbone for virtually all of the other elements just mentioned. To be more specific, I shall investigate connections between enslaving uses of the word "nigger" and the interpretation and application by courts and justice system professionals of slavery laws, fugitive slave laws, reconstruction laws or Black Codes, laws against discriminatory harassment in the workplace and on college campuses, the tort of intentional infliction of emotional distress, and the tort of defamation.

Even though I plan to investigate the role of the law in enabling illocutionary acts of enslavement, I shall not restrict my understanding of the nature of slavery and enslavement to legal definitions. Of course, in Jones v. Alfred H. Mayer Co. (392 U.S. 409), the US Supreme Court made it clear that congress possessed the power to "determine what are the badges and incidents of slavery, and the authority to translate that determination into effective legislation." But I do not propose to give a history of legislative and judicial interpretations of the Thirteenth Amendment (Tsesis 2009). Instead, I intend to take a theoretical approach to the concepts of slavery and enslavement. In particular, I shall follow the lead of other scholars who explicate these concepts using a range of typical features; none of which are necessary conditions, but all of which are themselves thick moral concepts. In particular, my theorization of slavery and enslavement will be influenced by the work of Julius Moravcsik - who conceives the "core of slavery" as involving features of oppression, exploitation, and forcible restrictions on life-affecting deliberations and choices (Moravcsik 1998) - and Orlando Patterson-who places an emphasis on domination, deracination, and degradation (Patterson 1982, 2012). For example, whereas oppression involves limiting the slave's opportunities for living by coercive means (Moravcsik 1998, pp. 172-3), degradation has to do with stripping the enslaved person of the sort of dignity that other people would normally be required to respect (Patterson 2012, p. 325) and domination has to do with holding the slave under the sway of arbitrary interference (ibid, p. 323; Pettit 1997, pp. 52-58). I shall also link the concepts of slavery and enslavement to yet another feature, subordination, an influential account of which can be found in the work of Rae Langton (1990). Subordination is itself multifaceted and may be constituted by ranking some groups of people as inferior to others, by legitimating discrimination against those groups, or by depriving those groups of rights and powers (Langton et al. 2012; Brown 2015, pp. 75-86). In some instances, the speaker can gain the authority to subordinate others through his or her speech when third parties remain silent 
and fail to object to the speech: their silence can "license" or grant authority to the speaker to subordinate others (Maitra 2012). That being said, I will argue that this sort of subordination rises to the level of enslavement only when it is combined with at least one of the other features of enslavement identified by Moravcsik and Patterson.

Consequently, when I ask the question, "Do some uses of the word "nigger" possess the power to enslave?" I have in mind a relatively capacious and fundamentally valueladen concept of enslavement, which draws on the aforementioned features, or subsets thereof, depending on the context. I do not claim that this is the only conceptual approach one could take. Nor shall I attempt here to demonstrate that it is the best. Instead, my argument takes the following conditional form. If enslavement has something to do with or is constituted by features a, b, c, (certain illocutionary acts) and if some uses of the words "negro," "nigger," "colored," and "black" possess the illocutionary power to $d o \mathrm{a}, \mathrm{b}$, and c in certain contexts, then it follows that some uses of the words "negro," "nigger," "colored," and "black" possess the illocutionary power to enslave in those contexts.

From a methodological perspective, therefore, my contribution will draw on and seek to further articulate the following interdisciplinary relationships: between the study of African American slavery and the study of law, legality, and legal institutions; between critical race theory, subordination theory, and the critical philosophy of race; between the phenomena of hate speech and the phenomena of enslavement; and between speech act theory and theories of enslavement.

My overall aim is to challenge conventional wisdom about the illocutionary power of the word "nigger." To this end, I shall also employ the rhetorical device of allegory. I tell the story of a fictional (but at the same time quite familiar) political community called Usonia. My story begins with an instance of the use of the word "nigger" by some Usonians, which it cannot be denied amounts to the performance of an illocutionary act of enslavement of other Usonians, and then by a series arguments by analogy, I try to show that a range of other uses of the word "nigger" also amount to the performance of an illocutionary act of enslavement. The story goes through a number of phases in this way until it reaches a point when the analogy is no longer possible or plausible; when the given use of the word "nigger" no longer amounts to the performance of an illocutionary act of enslavement. In short, if you think $\mathrm{w}$ is an illocutionary act of enslavement, then because of the similarities between $\mathrm{w}$ and $\mathrm{x}$, you must also think that $\mathrm{x}$ is an illocutionary act of enslavement, and similarly for $\mathrm{x}$ and $\mathrm{y}$, but because of the dissimilarity between $\mathrm{y}$ and $\mathrm{z}$, you need not to think that $\mathrm{z}$ is an illocutionary act of enslavement. All of this matters because the details of the story are sufficiently reminiscent of the situation in the USA. Nevertheless, the allegory serves to highlight and crystallize certain contextual features and thereby to enable a clearer understanding of the power of the word "nigger" to enslave.

Before I proceed with my story, however, I need to stress that it is customary in academic discussions of race, racist language, and racist social practices to rely on, and presuppose the moral significance of, the distinction between using and mentioning the word "nigger." Roughly speaking, the word is used when the speaker intends to refer to or pick out a person or group of people in virtue of dimensions of race or ethnicity; the word "nigger" is mentioned, by contrast, when it is the word itself or its usage that is the subject of discussion, including academic discussion. Mention is often indicated by inverted commas or speech marks (Saunders 2011, pp. 3, 156-7). When I use the word "nigger" in this article, it is always in the spirit of mentioning, not using. Following on from this, it is tempting to assume that whenever the word "nigger" plays a part in 
performing an illocutionary act of enslavement, it is being used rather than mentioned. Even so, this assumption needs to be supported with reasons; and that is what I shall try to do in the final section.

\section{The "Nigger" Slave}

Usonia was once a place where a population of pale-skin people held an equal sized population of dark-skinned people as their chattel slaves, having seized the latter from foreign, "uncivilized lands." Some of the slaves were set to work on the fields and some utilized as house slaves, especially the less dark-skinned amongst them. In fact, the laws of Usonia once permitted that if a pale-skinned person came upon a darkskinned person who was not already a slave or was a fugitive slave - whether in foreign lands or in Usonia itself - then merely for a pale-skinned person to point to a darkskinned person and utter the word "nigger" three times would be sufficient to turn the latter into the slave of the former. This was a kind of enslavement privilege that paleskinned Usonians had given themselves. Once classified as slaves, dark-skinned Usonians became property that could be bought, sold, and used for any purpose whatsoever. Surely, it would be impossible to deny that usage of the word "nigger" once had the power to enslave within this political community.

At first glance, the story might seem far-fetched. But consider three actual examples. The South Carolina Slave Code of 1740 declared that "all negroes and Indians, (free Indians in amity with this government, and negroes, mulattoes, and mustezoes, who are now free, excepted) mulattoes or mustezoes who are now, or shall hereafter be in this province, and all their issue and offspring [...] shall be and they are hereby declared to be, and remain hereafter absolute slaves" (Hurd 1858-62, p. 303). Subsequent decisions of the courts in South Carolina also confirmed that the ordinary meaning of the word "negro" matched that of the Slave Code. For example, in Ex parte Leland (1 Nott \& McCord 460), a case dating back to 1819, a South Carolina court held that the word "Negro" had the fixed meaning of "a slave." Within the boundaries of a society in which citizens are generally cognizant of, and compliant with, the aforementioned written and common law, simply being called "negro" could be sufficient to render a person a slave. This need not be restricted to oral expression of the word "negro." In the mid-nineteenth century, a Southern newspaper reported a story of a wealthy owner from St. Louis who branded his slave with the words "A slave for life" (Simkin 2014).

Second, in some jurisdictions, the law actively encouraged slave owners to make public declarations that would recommence the enslavement of fugitive slaves. In Barbados, for example, a seventeenth century slavery law made it an offense to harbor a "Runaway Negro" upon pain of paying ten thousand pounds in weight of merchantable muscovado sugar to the rightful owner for every day of the offense, and offered a reward of one hundred pounds of muscovado sugar for recapture of "Runaway Negros" (clauses 6 and 7 of An Act for the Better Ordering and Governing of Negroes, Barbados 1661) (Engerman et al. 2011, pp. 107-8). In the context of these sorts of laws, if a person captured someone who just so happened to be dark-skinned, he was empowered by law to call that person an "a Runaway Negro" and in so doing perform an illocutionary act of enslavement.

In the USA, of course, the Fugitive Slave Acts of 1793 and 1850 did not explicitly refer to "Negro" fugitives but instead to "a person held to service or labor in any State 
or Territory of the United States [who] has heretofore or shall hereafter escape into another State or Territory of the United States." Be that as it may, if a watchman, police officer, marshal, or deputy marshal, acting under warrants issued by the Circuit or District Court for the relevant districts to arrest fugitive slaves (colloquial known as "slave catchers"), captured a person, and if that person was without papers of identification or other proof of status (or even if the slave catcher seized and destroyed such papers), then the slave catcher had the authority granted by courts to determine if that person was a fugitive slave or not (Finkelman 2012, pp. 124-7). Under such circumstances, when a slave catcher called a person "negro" rather than "freeman," then that declaration more or less performed an illocutionary act of enslavement.

Third, under these systems of traditional slavery, human beings were treated as items of property and as such were the objects of full ownership rights. This extended to the children of slaves, including children born of a rape by white male plantation owners of African American house slaves. Thus, an owner had the power and the right to call the child "a mulatto"; the meaning of which was also "a slave." Of course, an owner also had the power and right to publicly acknowledge his own offspring, to refrain from calling the child "mulatto" and instead to free that child and even provide him or her with money, land, and slaves. Until the owner made a decision on this matter, the child was in some sense not yet enslaved. In this context, the use of the word "mulatto" also possessed the power to enslave (even a baby).

I have proffered three examples of the ways in which the use of the word "nigger" can, with the authority of the law, possess the power to enslave. I should now, however, like to add two caveats. The first is that even within a legal system of law which links being called a "negro," "nigger," or "mulatto" to being enslaved, nonetheless acts of defiance, insubordination, resistance, and non-compliance can persist. And some of these acts are themselves speech acts. Consider, "This here "nigger" says no sir, I ain't nobody's goddam property." Assuming the right sort of context, this utterance of the word "nigger" performs not the illocutionary act of enslavement but rather the illocutionary act of refusing to accept enslavement or the legitimacy of slavery laws.

Second, it would be wrong to suppose that illocutionary acts of enslavement are limited to the domain of slavery laws. Consider the criminal law as it pertains to sentences of penal labor, a slave-like form of existence. And consider the words that judges have in the past used in the sentencing of defendants. A graphic account of one such instance is captured in an article from 1942 published in The Rotarian, the official magazine of Rotary International (a voluntary society whose declared purpose is supporting humanitarian services and good will throughout the world). The article tells the story of Judge Charles M. Cooke, whom its author starts out by labeling, "former confederate solider, gentleman, scholar, human being” (Henderson 1942, p. 44).

Judge Cooke was a thorn in the flesh of Solicitor Porter Graves, one of the finest orators in Caswell County, North Carolina. [...] One time Solicitor Graves had got a conviction against an ash-faced, pigeon-chested, bowlegged Negro. The man had stolen a bag of corn.

"Now, Mister Solicitor," the Judge said with just a little more edge to his voice than usual, "you done got your little nigger convicted: what do you think I ought to do with him?" 
"Four years in the penitentiary," the Solicitor answered, matter-of-factly.

Judge Cooke looked at the Solicitor in amazement, and blurted out: "Four years, Mister Solicitor? [...] That's a long time Mister Solicitor. I fought four years in the Army of the Confederacy, and I know how long a time four years is. [...] You didn't mean four years in the pen for this sorry-looking little nigger who got hongry [sic.] and took a little corn to make ashcake with! Did you say F-O-U-R YE-A-R-S, Mister Solicitor?"

Turning to the clerk, Judge Cooke ordered, "Mister Clerk, the verdict of this court is that you send this little nigger to the country roads for 12 months. Justice will be met!" (ibid, p. 45)

The mere fact that Judge Cooke was regarded as something of a penal reformist in the eyes of The Rotarian - in virtue of his ordering only one-year hard labor-does not make it any less an illocutionary act of enslavement.

Now it might be objected at this point that the sentence ordered is not slavery or enslavement properly called since, first, the defendant was not treated as an item of property to be bought and sold, and, second, the defendant was in fact found guilty of stealing the bag of corn, meaning that his sentence brought about the lawful withdrawal or limitation of his rights and personal liberties. However, in response to the first point, it is unnecessarily restrictive to confine the words "slavery" and "enslavement" to cases of chattel slavery (Patterson 1982). When, for example, in Ruffin v. Commonwealth (62 Va. 790), a case dating back to 1871, a Virginia court commented that a prisoner is, as a consequence of his crime, "for the time being the slave of the state," it might have been speaking immorally and unconstitutionally, but it was not necessarily speaking nonsense or beyond the scope of any ordinary meaning of the word "slave."

Moreover, in response to the second point, if court proceedings and the deliberations and opinions of judges are marked by not only institutional racism but also the casual use of racist modes of address, and if the penal labor ordered in fact involved the forfeiture of $a$ substantial body of rights and personal liberties - including the convict's freedom of movement, his right to petition the Government for redress of grievances, his right not to labor, his right to a private life, and so on - then it is not too much of a stretch to think of Judge Cooke's use of the word "nigger" as an act of quasi-enslavement. Indeed, the fact that today more African Americans are locked away in prison than were enslaved in 1850, say, has not been lost on legal scholars and educators of young Americans. Pamela Monk Kelley of the Fellows of the Yale-New Haven Teachers Institute, for example, has dubbed the overrepresentation of African Americans in the criminal justice system and the penal system "the new enslavement of people of color" (Kelley 1996).

\section{The Free "Nigger"}

After many years of acrimonious debate and civil strife between slave owners and humanitarians of Usonia, it was decided to pass a law which abolished slavery. However, the fact of the change had not been widely publicized and was simply unknown to many, now former slaves. Large numbers of pale-skinned, slave-owning Usonians refused to 
recognize the new law as legitimate. Moreover, many district authorities passed new laws which enabled former slave owners to continue to control their former slaves. Laws allowed debt slavery, in which former slaves were given loans to purchase food, land, and licenses of various kinds, but their labor was demanded as a means of loan repayment and they spent the rest of their days in labor without ever repaying the debt. To achieve this, the former slave owner needed only to utter the words, "Nigger, you still owe me." Other laws allowed former slave owners to take as apprentices any children of former slaves whom authorities judged were not being adequately cared for. In practice, a former slave owner need only have to declare to a public official, "Those niggers ain't taking proper care of their child, so I say that nigglet should be my apprentice." What is more, apprentices were obliged to labor as instructed by their "Masters," and could be severely punished for showing defiance or attempting to run away. "You better do what I tells you nigglet, or else," their masters would warn. Even if the masters did not always carry out the threats of beatings, the mere fact that apprentices were at the mercy of the masters and lived under constant fear of violence sufficed for their domination. So while one form of slavery (Chattel slavery) had been abolished in Usonia, other forms of enslavement persisted (debt slavery, indentured servitude, involuntary servitude), as did the use of the word "nigger" to perform illocutionary acts of enslavement.

For those readers familiar with the history of reconstruction laws or Black Codes passed by Southern states after the Civil War, this aspect of the story of Usonia will have a ring of familiarity to it (Mangum 1940; Du Bois 1935; Ranney 2006; Williamson 1965). The forms of enslavement vindicated by the Black Codes were typified by an absence of the right to leave the employ of another, no right of decisionmaking over the processes of production, no aspect of daily labor left undirected, unsupervised, and uncontrolled by masters, and no prospect of sharing in the benefits of production. These were slave laws in all but name.

In time, even these laws were repealed in Usonia, and many former debt slaves found themselves working in its urban, semi-industrialized factories. But they soon realized that the factory owners and foremen were the masters of their own little citadels. Any foreman could announce to his staff, "For the rest of this month no goddam nigger will so much as break wind without checking that it's ok with me first." And he could do so because he had informal or discretionary power in virtue of his role or positional authority as foreman as well as formal powers delegated to him by the company's owners. In this way dark-skinned employees were the victims of subordination and domination of a sort that constituted a form modern enslavement, namely, a position of work devoid of any personal control, autonomy, or discretion; a position of work accepted in the absence of any reasonable alternative to its acceptance; a position of work defined by inferiority of status; a position of work based on vulnerability to another person's arbitrary interference over the nature and terms of that position; and a position of work characterized by menial labor with little or no skill, variety, or personal fulfillment. In Usonia, the vulnerability of dark-skinned people to this form of enslavement rested partly in the absence of laws against both discrimination and discriminatory harassment in the workplace.

This form of industrial slavery was a feature of the experience of many African American factory workers during the nineteenth and twentieth centuries.

It is one of the great ironies of American labor history that enslaved workers toiled at a wider variety of skilled tasks than did their descendants who were free. 
Slave owners had an economic incentive to exploit the multifaceted talents of blacks in the craft shop as well as in the kitchen and field. But after emancipation, whites attempted to limit blacks to menial jobs. Throughout the late nineteenth century and well into the twentieth, blacks as a group were barred from machine work within the industrial sector, and from white-collar clerical and service work. (Jones 2000)

\section{The Bitter Pill of Laws Against Discriminatory Harassment}

Even more time has elapsed and dark-skinned Usonians have taken their place in most spheres of commerce and industry, not to mention on college campuses. However, many light-skinned Usonians resent this state of affairs and routinely racially abuse and harass dark-skinned Usonians, especially those with the darkest skin of all. In response to the problem, public authorities in Usonia have created laws that in theory protect people against racist verbal abuse and harassment. But at the same time, the courts have also made the application of these laws extremely difficult. First, although victims of racist abuse can bring civil lawsuits for intentional infliction of emotional distress, in practice the courts place various obstacles in the way of establishing a cause of action in such cases. Second, a range of statutes, ordinances, and codes have been enacted to protect citizens from discriminatory harassment in the workplace and on college campuses, yet the courts do not make it easy for such laws to survive their scrutiny. The upshot is that dark-skinned Usonians are disproportionately victimized by racist verbal abuse and harassment, but at the same time find it difficult and sometimes virtually impossible to achieve redress or protection through the courts. "The courts fiddle while Usonia burns," as one satirical poet expressed the matter. What he really meant was that so long as the Usonian courts do not uphold and enforce laws on intentional infliction of emotional distress and discriminatory harassment, pale-skinned persons can continue to use the word "nigger" to subordinate, dominate, and enslave dark-skinned persons in the workplace and on college campuses with relative impunity.

Here too, the story of Usonia crystallizes the situation in American courts. Take the tort of intentional infliction of emotional distress. First, civil courts reserve this tort for "extreme and outrageous conduct," the determination of which is at the discretion of the courts (s. 46(1) of The Restatement of Torts (Second)). Although the situation has evolved more recently (Brown 2018), in the second half of the twentieth century, the vast majority of courts regarded the use of racial slurs like "nigger" as falling short of extreme and outrageous conduct. Consider Bradshaw v. Swagerty (1 Kan. App. 2d 213), Gomez v. Hug (7 Kan. App. 2d 603), Ugalde v. W. A. McKenzie Asphalt Co. $(990$ F.2d 239), and Walker v. Thompson (214 F.3d 615). Second, due to the existence of federal laws against discrimination and harassment in the workplace (Title VII of the Civil Rights Act of 1964), courts may be less likely to recognize or find in favor of plaintiffs in relation to emotional distress inflicted in the workplace because courts may implicitly assume that there are alternative, more appropriate ways for individuals to pursue their grievances, despite the relevant federal laws containing clauses making it clear that they do not de-bar civil proceedings (Chamallas and Wriggins 2010, p. 81). Third, even where adequate damages have been awarded by trial courts, courts of 
appeal have often slashed the amount of damages, citing insufficient or inadequate evidence of suffering or psychological injury, contributory conduct on the part of the plaintiff, or even jury bias, such as in Vance v. Southern Bell Tel. \& Tel. Co. (863 F.2d 1503).

Consider the 2014 case of Johnson v. Strive East Harlem Employment Group et al. (12 Civ. 4460). Here a US District Court drastically reduced the level of damages awarded by a lower court for the emotional distress suffered by an African American female employee as a result of being called a "nigger" by the defendant, a dark-skinned Puerto Rican male and head of the community employment organization which employed the plaintiff. The plaintiff, Brandi Johnson, recorded the following statement addressed to her by the defendant. "You and [a previous employee] are just alike. Both of you are smart as shit, but dumb as shit. You know what it is, both of you are niggers, y'all act like niggers all the time." The court reduced the damages inter alia on the grounds that the plaintiff had not explained to the court's pleasure the nature and purpose of the medication that her therapist had proscribed relating to the emotional distress caused by the defendant, that she had in fact decided not to take the medication, that she had been unable to fully articulate the mental and physical manifestations of her emotional distress, and that she had decided to record her interactions with the defendant. In other words, the court interpreted the plaintiff's decision not to divulge the nature of the medication not as a reasonable expectation of privacy but as evasion, her inability to fully articulate the nature of her distress not as itself part of the trauma but as a gap in evidence, and her recording of the conversation not as an attempt to get on record the pattern of abuse but instead as part of a calculated effort "to invite a confrontation" with the defendant.

To be racially abused in the workplace is to be stripped of status, control, authority, power, etc. It is not simply to work for others, it is to work under others. It is subordination as ranking people as inferior. Court decisions on the matter of what may or may not count as extreme and outrageous conduct can validate this sort of subordination. In addition, when appeal courts slash the damages awarded by lower courts, this may constitute subordination as depriving persons of the right to justice (adequate compensation). In these ways, courts can facilitate forms of enslavement.

Racial abuse on college campuses raises slightly different issues, but even here, courts may end up aiding and abetting illocutionary acts of enslavements. In order to demonstrate this, I return to my story. Toward the end of semester, a professor at one of Usonia's public universities divides students into working groups and assigns to each group an essay writing task. One particular group must write an essay together on the history of the slave trade. The professor has suggested a time and place when the group members should meet to discuss their essay and divide tasks and roles. At the same time, the professor has not devolved authority to any individual student. If a student is to speak with authority, he or she must obtain it in some other way. The group is comprised of five pale-skinned students and one dark-skinned student. After a few minutes of small talk, one of the pale-skinned students turns to the only dark-skinned student and says the following: "Hey, you're gonna write most of this paper aren't you? You know all about this stuff don't you? Anyway, I took a class with you last year, and, well, they say smart niggers are like the Easter Bunny, they don't exist, but you're the exception aren't you? Yes, you'll write the paper won't you?" The other white students do not object to the proposal, nor do they raise any word of complaint about the words 
used. In this sense, they grant him authority to speak for the group. The dark-skinned student feels embarrassed, distressed, angry, and put upon. But he also needs a good grade from the course in order to win a place at law school upon graduation. He does not consider going to the professor to complain because he suspects the other students will deny what happened and the professor will believe them. In the end, the dark-skinned student agrees to write the essay for the group. In virtue of the fact that he is a captive audience and oppressed by the conduct of the other students, and forced into exploitative labor for their benefit, one can argue that in this context the use of the word "nigger" is part of the performance of an illocutionary act of situational enslavement. A few weeks later, after the essay has been handed in and he has had a chance to reflect on the events, the student goes to the relevant college authorities to complain about what happened in the group. The authorities patiently explain that although they had previously enacted a campus speech code forbidding discriminatory harassment of precisely the sort he suffered, earlier in the year the code had been struck down as constitutionally overbroad and content discriminatory following a case brought to a Usonian appeals court by another pale-skinned student who believed that the code curtailed his free speech right to use the word "nigger" in commenting on issues of race.

Just as in Usonia, courts of appeal in the USA have played a significant part in protecting the rights of speakers to engage in such illocutionary acts on college campuses. Consider Doe v. University of Michigan (721 F. Supp. 852), UWM Post v. Board of Regents of the University of Wisconsin (774 F. Supp. 1163), Dambrot $v$. Central Michigan University (55 F.3d 1177), and Corry v. Stanford (No. 740309).

\section{Life Beyond the Protected Zones of Discriminatory Harassment Laws}

Today the citizens of Usonian enjoy far greater protection against discriminatory harassment than ever before. Courts recognize the power of the word "nigger" to inflict emotional distress and appeal courts no longer routinely slash damages. Moreover, judges are no longer absolutist in their interpretation of the right to freedom of expression, and so statutes, ordinances, and codes against discriminatory harassment in the workplace and on college campuses are more likely to survive judicial scrutiny. Even so, some pale-skinned Usonians still use the word "nigger" to publicly abuse, stigmatize, degrade, and humiliate dark-skinned members of the community outside of the protected domains of the workplace and college campuses. Being the victim of this sort of racial abuse or harassment can happen to a dark-skinned Usonian at almost any time - on the drive into work, on the street corner, in a cinema, at the mall, on an airplane, during town meetings, in the swimming baths, on the golf course - the only uniting feature is that it happens without notice, it cannot easily be avoided, and its occurrence is under the arbitrary decision of the speaker. Dark-skinned Usonians cannot escape it; they are trapped by a life that carries a constant threat of racial abuse. They are in that sense still enslaved by the use the word "nigger."

Now some people might argue that the allegory has passed the Rubicon of any sensible usage of the term "enslaved." Many of the examples discussed above revolve around work and the treatment of other people qua workers. Focusing on such cases makes it easier to invoke the ideas of slavery and enslavement since those ideas connote forced labor (so the objection runs). However, the scope of the ideas of slavery and 
enslavement need not be limited to the putting to work of human beings. The idea of enslavement can be applied just as meaningfully to more generalized circumstances, most notably unequal relationships of power and control, such as within a racist society. In doing so, the idea of enslavement encompasses its close cousins, subordination and domination; both of which can be instantiated by the systematic and widespread use of racial slurs in civil society.

Here too the law can function as an enabler of illocutionary acts of enslavement. For one thing, whether or not citizens enjoy security (or non-domination) in relation to enslaving uses of the word "nigger" rests on how lawmakers respond to the challenge of deterring such speech conduct. Counter-speech has always had its limitations as an effective and viable option for vulnerable minorities, and it probably always will have. So, in the absence of proper legal protection, there is bound to be more insecurity (domination). Moreover, if the environment in which persons live is one of racial abuse unfettered and unrestrained by the law, then people lack one source of assurance that they are members of the community in good standing. This, at least, is the argument recently put forward by the legal and political theorist Jeremy Waldron in defense of group libel laws (Waldron 2010, p. 1626). Waldron also happens to think that criminal law has a singularly important role to play in this process of assurance, since it is concerned with the fundamentals of reputation or the civic dignity of entire groups of people, not least racial or ethnic groups (ibid, p. 1600). In his view, civil law is more concerned with the finer details and the ebb and flow of an individual's personal reputation and with her personal response to the racist slings and arrows that may or may not come her way (ibid, pp. 1607-8).

I happen to disagree. In civil proceedings it is the individual concerned, not the public prosecutor, who decides to bring a case, to drop a case, to accept an out of court settlement, to fight on for damages, to file an appeal if she loses in trial court, to join or not join with others in a class action, and so on. In other words, in civil proceedings the plaintiff is to a greater extent the master of his or her own destiny. And when it comes to the question of enslavement, this mastery counts for something. Consequently, I think there is a strong case to be made for the use of tort law in combating enslaving uses of the word "nigger" - a case that can be made by appealing to human dignity as freedom from the sort of degradation and humiliation that can also have the effect of enslaving (subordinating and oppressing) its victims (Brown 2018).

And yet, what of the abovementioned obstacles to successful recovery for the tort of intentional infliction of emotional distress? One option here is to lobby legal professionals and legislators to remove or mitigate the impact of these obstacles. A second option is more radical: to introduce a bespoke new tort. For example, in 1982 the wellknown critical race theorist Richard Delgado published an article in the Harvard Civil Rights-Civil Liberties Law Review proposing a new tort of racial insult (Delgado 1982). With this tort, the plaintiff would need to prove only that a term of racial abuse had been used against him or her, and with the intent to demean (ibid. p. 179). He or she would not need to prove concrete psychological or physiological effects over and above the injury to dignity itself (ibid, p. 171). Accordingly, there would be no onus on courts to apply the extreme and outrageous conduct test (ibid, p. 153). Other potential advantages worth mentioning here-albeit not ones explicitly highlighted by Delgado - are, first, that the tort is not limited to instances of discriminatory harassment in the workplace and on college campuses, and, second, that the tort could be applied 
even to cases in which members of the same racial group insulted one another, such as if one African American called another African American a "nigger" with intent to demean (ibid., pp. 179, 180n.275).

Elsewhere, I have proposed a new dignity-based theoretical analysis of both the tort of international infliction of emotional distress and Deldado's tort of racial insult, with an emphasis on whether the speech in question was degrading or humiliating. I have also developed legal tests for degradation and humiliation including the condition that the speaker stands in a position of authority (Brown 2018).

\section{The Power of the Language of Civil Courts}

The courts of Usonia have now come to recognize the tremendous importance of tort law in protecting citizens against harmful expressive conduct. They begin to accept both the tort of intentional infliction of emotional distress and the tort of racial insult as relevant to cases involving racially abusive uses of the term "nigger." But at the same time, they are mindful that justice must be seen to be fair. So the courts trip over themselves in protecting the rights of pale-skinned Usonians not to be injured by the speech of others. They hear a growing number of cases in which light-brownishskinned Usonians are called "niggers," and they grant damages for the tort of defamation to the individuals concerned. The courts see that for a light-brownish-skinned Usonian to be called a "nigger" could inflict reputational damage, such are the continued negative connotations of the term. Here the courts only mention the word "nigger" in their judgments, but nevertheless the courts (inadvertently) also perform an illocutionary act of ranking as inferior dark-skinned Usonians.

In this final stage of my allegory the attention is turned to the fact that sometimes courts themselves may (unwittingly) perform illocutionary acts of subordination. Earlier I touched upon the use of racial epithets by judges. Be that as it may, the last part of my story is focused on subtler modes of judicial subordination, when courts mention rather than use terms of racial abuse. Civil courts can perform an illocutionary act of subordinating racial groups in virtue of declaring that certain sorts of words, such as "black," "negro," or "nigger," are defamatory. For example, a court might utilize the test that a statement is defamatory if considered so by the general community or the prevailing public policy. If the general community standard and prevailing public policy is that African Americans are of inferior character and status to white Americans and that racial segregation is an appropriate response to that inferiority, then in applying this test courts are likely to find that misidentifying a white person as a "negro" amounts to disparagement in the eyes of an ordinary or reasonable member of that community. Consider Upton v. Times-Democrat Pub. Co. (104 La. 141), Flood v. News \& Courier Co. (50 SE 637), May v. Shreveport Traction Co. (127 La. 420), Jones v. RL Polk \& Co. (190 Ala. 243), Collins v. Oklahoma State Hospital (76 Okla. 229), Hargrove v. Oklahoma Press Pub. Co. (130 Okla. 76), Atlanta Journal Co. v. Farmer (48 Ga. App. 273), Natchez Times Publishing Co v. Dunigan (221 Miss. 320), and Bowen v. Independent Publishing Co. (230 S.C. 509). This, I argue, is to perform an illocutionary act of ranking African Americans as inferior by vindicating community standards relating to the low standing and acceptable ill-treatment of members of that group. However, I do not believe that this rises to the level of enslavement. By 
themselves, acts of ranking and vindicating may suffice to constitute subordination, but not enslavement. For enslavement to obtain, at least one other feature of slavery is required, such as oppression, domination, or exploitation.

Of course, where a community has a more progressive attitude toward race and racial minorities, the general community standard test will also reflect that fact. In other words, the outcome of applying the test to the word "nigger" will change over time with the evolving content of community standards. For instance, in Irving v. J. L. Marsh Inc. (46 Ill. App.3d 162) an Appellate Court of Illinois dismissed a cause of action for defamation based on its rejection of the proposition that the word "nigger" is defamatory in its ordinary meaning. In the words of the Court (at 166):

In arguing that the racial slur "nigger" implies that an individual is generally lacking in the virtues of honesty, intelligence or creativity, we believe plaintiff attributes a definition to the words that is far in excess of its meaning. The words used by defendant's salesman do not impute an inability to perform or want of integrity in the discharge of the duties of office or employment.

At the same time, courts have held that stating or strongly implying that someone is a white racist or bigot or else has performed racist or bigoted acts is regarded as defamatory by general community standards (i.e., capable of lowering the esteem in which that person is held in the general community). Consider Afro-American Publishing Co v. Jaffe (366 F.2d 649) and MacElree v. Philadelphia Newspaper, Inc. (55 N.Y.2d 433).

Now, it is all well and good if general community standards have changed, but what if they remain static? The philosopher R. M. Hare once intimated that the language of the Southern states was static because closed to change. "[If] we want, in the Southern States, to speak to a negro as an equal, we cannot do so by addressing him as a nigger; the word "nigger" encapsulates the standards of the society, and, if we were confined to it, we could not break free from those standards" (Hare 1963, p. 25). But should not the law be in a position to challenge and reform general community standards? Should not members of the legal profession sometimes be prepared to act as "norm entrepreneurs" or even civic educators when they are faced with general community standards which they know in their hearts to be unjust? To recycle a turn of phrase used by the abolitionist Samuel Bass in Solomon Northup's Twelve Years a Slave, when the law says that being called a "nigger" is to impute to the plaintiff an inability to function as a normal member of civil, political, and professional life, the law is a liar (Northup 2008, p. 266). And consider the ideal of the heroic lawyer symbolized by the character Atticus Finch in Harper Lee's To Kill a Mocking Bird who offers the following pedagogical mention of the word "nigger."

"Scout," said Atticus, "nigger-lover is just one of those terms that don't mean anything-like snot-nose. It's hard to explain - ignorant, trashy people use it when they think somebody's favoring Negroes over and above themselves. It's slipped into usage with some people like ourselves, when they want a common, ugly term to label somebody." "You aren't really a nigger-lover, then, are you?" "I certainly am. I do my best to love everybody... I'm hard put, sometimes - baby, it's never an insult to be called what somebody thinks is a bad name. It just shows you how poor that person is, it doesn't hurt you." (Lee 1989, p. 120) 
What is to be done then? One alternative is for courts to consciously adopt the maxim of refraining from official subordination of racial minorities by not giving effect to or vindicating racist community standards concerning the meaning of "ugly terms." If granting damages to plaintiffs on the basis that the general community would find being called "black," "negro," or "nigger" disparaging amounts to the ranking of races or the judicial vindication of subordinating community standards, then courts should elect instead to redefine the notional category of the ordinary or reasonable person so as to include those individuals who are more tolerant, progressive, and egalitarian in their viewpoints. Insofar as being called these names would not lower someone in the eyes of such individuals, the plaintiff cannot expect these words to be categorized as defamatory. Putting this another way, I am advocating that courts substitute the general community standards test (Baker 2008, p. 12) with a more flexible, contextual, and critical moral approach to determining the makeup of the community of people that is to be utilized in determining whether or not statements are defamatory. Even so, as argued above, victims of racial abuse should still have recourse to other types of tort as means of redress against genuinely enslaving uses of the term "nigger."

Open Access This article is distributed under the terms of the Creative Commons Attribution 4.0 International License (http://creativecommons.org/licenses/by/4.0/), which permits unrestricted use, distribution, and reproduction in any medium, provided you give appropriate credit to the original author(s) and the source, provide a link to the Creative Commons license, and indicate if changes were made.

\section{References}

Austin, J. L. (1962). How to do things with words. Oxford: Oxford University Press.

Baker, R. (2008). Defamation and the moral community. Deakin Law Review, 13, 1-35.

Brown, A. (2015). Hate speech law: A philosophical examination. London: Routledge.

Brown, A. (2017a). What is hate speech? Part 1: The myth of hate. Law and Philosophy, 36, 419-468.

Brown, A. (2017b). What is hate speech? Part 2: Family resemblances. Law and Philosophy, 36, 561-613.

Brown, A. (2018). Retheorizing actionable injuries in civil lawsuits involving targeted hate speech: Hate speech as degradation and humiliation. Alabama Civil Rights and Civil Liberties Law Review, 9, 1-56.

Brown, A., \& Sinclair, A. (2019). The politics of hate speech laws. London: Routledge.

Butler, J. (1997). Excitable speech: A politics of the performative. New York, NY: Routledge.

Chamallas, M., \& Wriggins, J. B. (2010). The measure of injury: Race, gender, and tort law. New York: New York University Press.

Delgado, R. (1982). Words that wound: A tort action for racial insults, epithets, and name-calling. Harvard Civil Rights-Civil Liberties Law Review, 17, 133-181.

Du Bois, W. E. B. (1935). Black reconstruction in America 1860-1880. New York: Harcourt, Brace and Company.

Engerman, S. L., et al. (Eds.). (2011). Slavery. Oxford: Oxford University Press.

Finkelman, P. (2012). Slavery in the United States: Persons or property? In J. Allain (Ed.), The legal understanding of slavery: From the historical to the contemporary. Oxford: Oxford University Press.

Hare, R. M. (1963). Freedom and reason. Oxford: Oxford University Press.

Henderson, T, (1942) True tales of a judge. The Rotarian, December, 44.

Hurd, J. C. (1858-62) The Law of Freedom and Bondage in the United States, Vol. 1. Boston: Little, Brown \& Company.

Jones, J. (2000) Black workers remember. American Prospect, November 30. Available at: https://prospect. org/article/black-workers-remember. Last accessed 04/04/2019.

Kelley, P. M. (1996) Multiculturalism and the law: The criminal injustice system the new enslavement of people of color. Curriculum Units by Fellows of the Yale-New Haven Teachers Institute 1996, Vol. 1. Available at: http://yale.edu/ynhti/curriculum/units/1996/1/. Last accessed 04/04/2019. 
Kennedy, R. (1999). Who can say "nigger"? And other considerations. The Journal of Blacks in Higher Education, (26), 86-96.

Kennedy, R. (2003). Nigger: The strange career of a troublesome word. New York: Vintage Books.

Langton, R. (1990) Subordination, silence, and pornography's authority. In R. Post (Ed.), Censorship and silencing: Practices of cultural regulation. Los Angeles: Getty Research Institute for the History of Art and the Humanities.

Langton, R., et al. (2012). Language and race. In G. Russell \& D. Graff Fara (Eds.), Routledge companion to the philosophy of language. London: Routledge.

Lee, H. (1989). To kill a mocking bird. London: Arrow Books.

Maitra, I. (2012). Subordinating speech. In I. Maitra \& M. McGowan (Eds.), Speech and harm: Controversies over free speech. Oxford: Oxford University Press.

Mangum, C. (1940). The legal status of the negro. Chapel Hill: The University of North Carolina Press.

Moravcsik, J. (1998). Slavery and the ties that do not bind. In T. L. Lott (Ed.), Subjugation and bondage: Critical essays on slavery and social philosophy. Lanham: Rowman and Littlefield.

Morrison, T. (Ed.). (1992). Race-ing justice, en-gendering power: Essays on Anita Hill, Clarence Thomas, and the construction of social reality. New York: Pantheon Books.

Nelson, R. (1998). The word "nigga" is only for slaves and sambos. The Journal of Blacks in Higher Education, (21), 117.

Northup, S. (2008). Twelve years a slave. Bedford: Applewood Books.

Patterson, O. (1982). Slavery and social death. Cambridge: Harvard University Press.

Patterson, O. (2012). Trafficking, gender and slavery: Past and present. In J. Allain (Ed.), The legal understanding of slavery: From the historical to the contemporary. Oxford: Oxford University Press.

Pettit, P. (1997). Republicanism: A theory of freedom and government. Oxford: Oxford University Press.

Ranney, J. A. (2006). In the wake of slavery: Civil war, civil rights, and the reconstruction of southern law. Westport: Praeger.

Roberts, R. C. (2010). The morality of using “nigger”. In D. Golash (Ed.), Freedom of expression in a diverse world. Dordrecht: Springer.

Saunders, K. W. (2011). Degradation: What the history of obscenity tells us about hate speech. New York: New York University Press.

Simkin, J. (2014). Slavery in the United States. Spartacus Educational Publishers.

Tsesis, A. (2009). Interpreting the thirteenth amendment. University of Pennsylvania Journal of Constitutional Law, 11, 1337-1362.

Waldron, J. (2010). 2009 Oliver Wendell Holmes lectures: Dignity and defamation: The visibility of hate. Harvard Law Review, 123, 1596-1657.

Williamson, J. (1965). After slavery: Negro in South Carolina during reconstruction (pp. 1861-1877). Chapel Hill: University of North Carolina Press.

Publisher's Note Springer Nature remains neutral with regard to jurisdictional claims in published maps and institutional affiliations. 